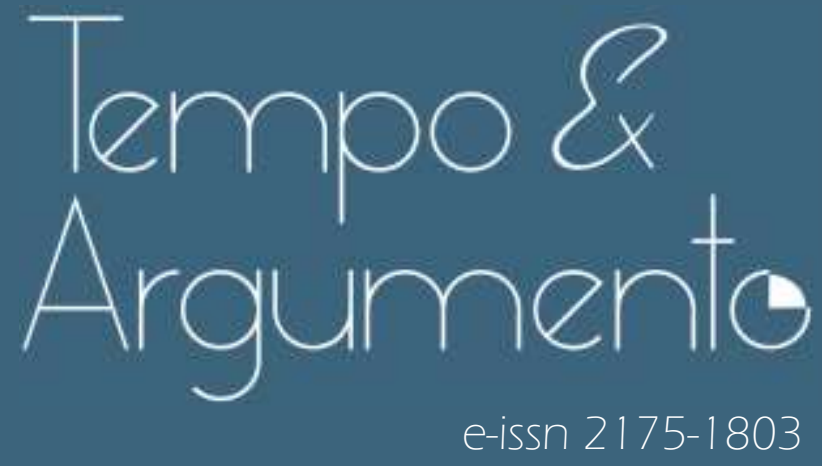

\title{
A "luta" e as (in)verdades de conjuntura, a independência de São Tomé e Príncipe e a amputação das liberdades dos são-tomenses
}

4. Augusto Nascimento

Doutor em Sociologia e com Agregação em História Contemporânea pela Universidade Nova de Lisboa (NOVA).

Investigador no Centro de História da Universidade de Lisboa (ULisboa).

Lisboa - PORTUGAL cienciavitae.pt/E415-6745-1676 augusto.nasci@campus.ul.pt

(D) orcid.org/0000-0002-1870-1986

Para citar este artigo:

NASCIMENTO, Augusto. A "Iuta" e as (in)verdades de conjuntura, a independência de São Tomé e Príncipe e a amputação das liberdades dos sãotomenses. Tempo e Argumento, Florianópolis, v. 13, n. 34, e0 105, set./dez. 2021.

do) http://dx.doi.org/10.5965/2175180313342021 e0105

Recebido: 02/05/2021 Aprovado: 02/08/2021 
A "luta" e as (in)verdades de conjuntura, a independência de São Tomé e Príncipe e a amputação das liberdades dos são-tomenses

Augusto Nascimento

\title{
A "luta" e as (in)verdades de conjuntura, a independência de São Tomé e Príncipe e a amputação das liberdades dos são-tomenses
}

\begin{abstract}
Resumo
Este texto tenta abordar o modo como a "luta" pela independência de São Tomé e Príncipe se constituiu numa narrativa inquestionada - aliás, não foi narrada por ter pouco que contar e por convir calar o que era sabido por alguns e intuído pelos ithéus entrementes desapossados de voz -, mas com implicações políticas, entre elas, a aceitação do domínio de uns tantos sobre a maioria. A aliciante disrupção da "luta" a destempo após o 25 de Abril turvou a racionalidade, eliminou as possibilidades de escolha e, na circunstância, contribuiu para a gestação de novas dominações, independentemente da alegria do momento da independência e da certeza da mais que provável vitória do MLSTP se tivesse havido um referendo ou eleições sobre o rumo do arquipélago.
\end{abstract}

Palavras-chave: São Tomé e Príncipe; colonialismo; independência; conhecimento histórico.

The "struggle" and the (un)truths of the situation, the independence of São Tomé and Príncipe and the amputation of the freedoms of Sãotoméans

\begin{abstract}
This text deals with the way in which the "struggle" for the independence of São Tomé and Príncipe was constituted in an unquestioned narrative - moreover, it was not narrated because it had little to tell and because it was convenient to silence what was known by some and intuited by the islanders meanwhile dispossessed of voice - but with political implications, among them, the acceptance of the dominance of a few over the majority. The enticing disruption of the "struggle", after 25 April, blurred rationality, eliminated the possibilities of choice and, in the circumstances, contributed to the creation of new dominations, regardless of the joy of the moment of independence and the certainty of the most likely victory of the MLSTP if there had been a referendum or elections on the course of the archipelago.
\end{abstract}

Keywords: São Tomé and Príncipe; colonialism; independence; historical knowledge.

\section{La "lucha" y las (des) verdades de la situación, la independencia de Santo Tomé y Príncipe y la amputación de las libertades}

\section{Resumen}

Este texto intenta aproximarse a la forma en que la "lucha" por la independencia de Santo Tomé y Príncipe se constituyó en una narrativa incuestionable - además, no fue narrada porque tenía poco que contar y porque convenía silenciar lo conocido. por algunos e intuido por los isleños desposeídos de voz - pero con implicaciones políticas, entre ellas, la aceptación del dominio de algunos sobre la mayoría. La tentadora ruptura de la "lucha" ya después del 25 de abril desdibujó la racionalidad, eliminó las posibilidades de elección y, dadas las circunstancias, contribuyó a la creación de nuevos dominios, independientemente de la alegría del momento de la independencia y la certeza de la Victoria más que probable del MLSTP si hubiera habido referéndum o elecciones en el transcurso del archipiélago.

Palabras clave: São Tomé e Príncipe; colonialism; independencia; conocimiento histórico. 
A "luta" e as (in)verdades de conjuntura, a independência de São Tomé e Príncipe e a amputação das liberdades dos são-tomenses

Augusto Nascimento

\section{Introdução}

"Nós nunca escondemos nem vamos esconder nada ao nosso povo. Ele tem o direito de saber o que se passa, só ele é que será capaz de distinguir o verdadeiro do falso, de dar razão àqueles que a merecem.” (COSTA, 1978, p. 37) Estas foram palavras do então líder do Movimento de Libertação de São Tomé e Príncipe (doravante, MLSTP), Pinto da Costa, a 9 de abril de 1975, num comício em São Tomé. Hoje, perguntar-se-ia como é que se as proferia e porque é que o "povo" acreditaria em tais palavras...

Devido à crença na linearidade e na inevitabilidade do progresso, à data não existiria uma clara compreensão dos escolhos apostos ao novel país. Ora, aquela crença tornou-se uma fonte de políticas equivocadas, mesmo se os equívocos se afiguravam impossíveis dados os propósitos emancipatórios. Mesmo se, já por essa altura, não raro os propósitos emancipatórios se apartavam da realidade.

A considerar-se a independência de São Tomé e Príncipe como um valor per se, quando não absoluto², não só se prejudicará a interpretação dos eventos históricos ${ }^{3}$, como se terá de se explicar o inexplicável de alguns dos seus protagonistas afirmarem desde há anos que em 1974-1975 se poderia ter adotado outra solução política ${ }^{4}$, por exemplo, uma federação ou uma independência não imediata e socialmente menos disruptiva ${ }^{5}$. À época, esta seria a opção de alguns ilhéus que, por inépcia ou medo, se coibiram de a propor. Foram apodados de

\footnotetext{
Nesse texto optou-se por manter a grafia da língua nativa.

A independência do arquipélago equivalia à libertação de décadas de um regime ditatorial ou, segundo a alusão simplista dos novos dirigentes, de uma opressão de séculos. Ora, mais do que gerar resistência, o regime ditatorial obrigara à tergiversação e à contemporização com o colono. 2 Em 1975, cerca de década e meia após as independências africanas, uma tal perspetiva prevalecia por parecer inexistir alternativa à independência num mundo envolto numa confrontação político-ideológica.

${ }^{3}$ Adotar a independência como valor absoluto - ignorando o que esse valor comporta de histórico - implica amputar a explicação e até a pluralidade dos dados a compulsar numa descrição densa dos eventos em São Tomé e Príncipe.

${ }^{4}$ Diga-se, asserções deste tipo (testemunho pessoal) contrastam com outras afirmações públicas dos mesmos atores. Seja como for, o tempo mostrou como nem mesmo para aqueles que a advogavam "total e completa" a independência permaneceu como um valor absoluto.

Sopesadas a exiguidade social e a forçosa interação pessoal nas ilhas, não revelo os autores dos testemunhos, alguns, como este, feitos pessoalmente, outros em segunda mão.

${ }^{5}$ É possível entrever mudanças de opinião acerca da independência consoante a situação do país em sucessivos momentos. Acresce a oscilação de opiniões sobre a "identidade" e a inserção geoestratégica conforme expetativas em torno de personagens redentores ou, noutro plano, de adventícias receitas, como se esperava que tivessem sido as do petróleo (NASCIMENTO, 2001).
} 
A "luta" e as (in)verdades de conjuntura, a independência de São Tomé e Príncipe e a amputação das liberdades dos são-tomenses

Augusto Nascimento

reacionários, quando, afinal, apenas não tinham força para fazer valer as suas reticências ${ }^{6}$ face ao caminho imposto pelo MLSTP embalado por circunstâncias históricas e por verdades de conjuntura. Donde advinha a força do MLSTP? Decerto, dos efeitos política e socialmente corrosivos da insanável matriz do colonialismo, de feição ditatorial no seu derradeiro meio século, cuja rejeição, quando subitamente possibilitada pelo 25 de Abril, se tornou um imperativo transcendente para os ilhéus. E, conforme então se repetiu incessantemente, o peso do MLSTP advinha da "luta"'. Como à época, durante anos esta asserção permaneceu incontestada. E desta pressuposta verdade brotaram consequências no plano do conhecimento historiográfico.

A este respeito, importará relembrar, por um lado, que a compreensão e a empatia sugeridas pelo sofrimento pregresso de populações colonizadas também se revelaram uma fonte de erros e, por outro, que o facto de os atores se dizerem protagonistas de uma "luta" não obriga à adesão acrítica a tais enunciações. A análise das narrações da "luta” do MLSTP revela um emaranhado de asserções díspares, nas quais dificilmente se descortina coerência, salvo nas proclamações de valores abstratos - transacionados pelo seu valor facial e irrebatíveis porque autorreferenciados -, distantes da realidade e cujas consequências, assaz danosas a nível político, económico e social, recaíram sobre os mais desapossados dos ithéus e demais africanos...

Mais do que sobre a "luta" pela independência, este texto versa sobre a difusa narrativa histórica de tal "luta”, cuja elaboração, aos olhos dos dirigentes, só poderia ser - se ela se tivesse escrito, no que não existiu interesse - a de um percurso exaltante ${ }^{8}$.

\footnotetext{
${ }^{6}$ Note-se, o desvio de finalidade e o imprevisível contaminam a maior parte das ações humanas, incluindo, por maioria de razão, as decorrentes de promessas ideológicas e de palavras redentoras. Naquela conjuntura, as crenças ideológicas impediram a ponderação de dúvidas que, aliás, nem sequer puderam ser expostas.

Para a maximização dos dividendos da "luta" foi importante a luta a destempo, a mobilização da rua, empreendida pelos jovens da Associação Cívica Pró-MLSTP a partir de junho de 1974 , (NASCIMENTO, 2019; SEIBERT, 2002).

${ }^{8}$ A ser feita, tal narração comungaria do corriqueiro viés epopeico de histórias de Estados de diversa coloração política, inclusive, o Estado colonial. Fosse com fosse, a "luta" do MLSTP não se revestia da heroicidade de outras lutas, heroicidade não raro relembrada ad nauseam pelos seus atores, caso, por exemplo, da basta produção memorialista em Moçambique, analisada por Chaves (2019).
} 
A "luta" e as (in)verdades de conjuntura, a independência de São Tomé e Príncipe e a amputação das liberdades dos são-tomenses

Augusto Nascimento

Embora a "luta" dos exilados tivesse sido rala e deslaçada, revelou-se crucial exponenciá-la simbolicamente, ao mesmo tempo que se lançava opacidade sobre o seu curso. Era imperativo enraizar a noção de que a "luta" fora determinante para assim se lograr a adesão dos ilhéus, não à independência, mas ao MLSTP em detrimento de outros eventuais protagonistas. Para tal, a fé nas palavras dos putativos dirigentes era mais decisiva do que o conhecimento detalhado dos eventos. A tal fé ajudava o facto de não se poder questionar nenhuma dessas palavras, atentos tanto o entusiasmo quanto o medo gerados pela hipótese de independência escancarada pelo 25 de Abril.

A crença na "luta" substituiu o escrutínio da narração. Acima de qualquer outra evidência estava o seu sucesso, provado pela independência vindoura ${ }^{9}$. Esta entroncava no fluxo da história, como irrefutavelmente o patenteava a disposição demissionária do colono que, antes fincado na sua soberania, claudicava e entregava o poder. Ora, apesar destes factos, a narrativa da "luta" só era incontestável por força do enlevo de parte dos ilhéus e pelo constrangimento que impendeu sobre os demais, precocemente sujeitos ao medo e aos ditames da "luta" que, pela ação da Associação Cívica (doravante, Cívica), a destempo irrompia na rua a favor da independência total e completa.

Premissa de um futuro ridente, a "luta" do MLSTP não era para ser conhecida, era para ser acreditada. Sonegando-se o conhecimento, demandavase crença no passado aludido pelos dirigentes que, mais do que se quererem exemplo de ação, se queriam olhados como dirigentes. A "luta" caracterizara-se pela cizânia, pela inépcia, pela desagregação e, por fim, pela mistificação. Todavia, em 1974, tudo passaria a ser de somenos perante a inebriante perspetiva da independência. A verdade era negligenciável face a um cometimento político transcendente - crê-lo-iam muitos, até parte dos atores - em prol do povo. Adiantemo-lo, malgrado o indiscutível valor abstrato da independência, em muitos domínios das vidas pessoais e coletiva não haveria ganhos.

\footnotetext{
Dada a exaltação política, compreende-se a seleção da história narrada pelos atores. A inferência da verdade do que diziam, que não provavam, baseava-se na denúncia da indesmentível imoralidade do colonialismo e nas verdades de conjuntura sobre o curso da história. Baseava-se igualmente, quando não sobretudo, no seu putativo poder. A veracidade do que se alegava não carecia de prova - tal demanda era impensável por sacrílega -, antes decorria da proeminência de quem a enunciava. Entende-se que assim tenha sucedido, mas esta substituição da prova pela crença não tem de ser adotada por estudiosos.
} 
A "luta" e as (in)verdades de conjuntura, a independência de São Tomé e Príncipe e a amputação das liberdades dos são-tomenses

Augusto Nascimento

Atentas as imbricações das políticas com os erros das narrativas históricas, pretende-se, então, indagar o modo como se extraíram ilações acerca do curso da história, as quais ajudaram a abrir uma senda política, anunciada por lemas apelativos mas (possivelmente) avessos a anseios das pessoas que compunham o tão celebrado "povo". Foi assim que, de permeio com a libertação da colónia, as ilações decorrentes da narrativa da "luta" - rumo a uma "independência verdadeira" - tornavam como que compreensíveis as amputações das liberdades dos cidadãos ${ }^{10}$.

Neste ambiente, o papel da narrativa da "luta” não se cingiu ao domínio das representações ou dos sentimentos de pertença à nação. Em si mesma, a narrativa era menos importante do que o era a ilação, a interiorizar pelos cidadãos, de que da "luta" e do curso do mundo decorria o dever de lealdade para com os novos mandantes, protagonistas excelsos da história. A homenagem à pregressa "luta" do "povo" contra a ignomínia colonial obrigava à comunhão dos desígnios da "independência verdadeira" e à lealdade para com o MLSTP. Na prática, para com o chefe. Episodicamente, esta transação entre independência e dívida de lealdade pareceu até suscitar adesão.

Uma vez possível, a independência ganhou adeptos como se ela tivesse sido uma ambição de toda uma vida. Por empatia das lutas noutras colónias e do 25 de Abril, a efervescência na rua e a subsequente ação política empurraram para a independência ou, mais precisamente, para uma independência que, como alguns anteviam mas calaram por medo face ao inelutável desenlace político, se tornaria uma canga para grande parte dos ilhéus. A libertação do país não trouxe a emancipação dos cidadãos.

\section{A rasura da história... ou uma militância feita "luta"}

No tocante à "luta", aduzam-se alguns dados para melhor se entender a dinâmica política em 1974-1975. Nos anos precedentes, nas ilhas, para além do apego à terra, grassaria nalguns ilhéus um ressentimento calado face ao colono. Mas, afora conversas num grupo de jovens politizados, não existia ação política. Aliás, a maioria dos ithéus não imaginaria outro destino que não o que sempre

${ }^{10}$ Antes do 25 de Abril, o arauto desta senda foi o jornal da Cívica, Presença de S. Tomé e Príncipe. 
A "luta" e as (in)verdades de conjuntura, a independência de São Tomé e Príncipe e a amputação das liberdades dos são-tomenses

Augusto Nascimento

parecera prescrito e, malgrado tensões, natural. Fora, a militância independentista resumira-se a ações de propaganda de impacto duvidoso, quando não nulo, na maioria da população islenha e, sobretudo, à presença dos nacionalistas em fóruns internacionais na busca de reconhecimento ${ }^{11}$, tal o trunfo para, no arrasto do desenlace político ou militar da guerra noutras colónias, reivindicarem a independência. Contudo, não menos relevantes tinham sido as dissensões, por vezes acompanhadas de acusações graves (SEIBERT, 2002, p. 96-97), alternadas com reagrupamentos, desde os dos CLSTP ${ }^{12}$ até ao do MLSTP'13. Mesmo no ato de congregar vontades, em 1972, não faltou o traço de desunião ${ }^{14}$, a que se seguiria a dispersão imposta pelas circunstâncias das vidas pessoais. Já após o 25 de Abril, o sentido de oportunidade, que anos antes levara à transmutação dos CLSTP no MLSTP, ditaria o silêncio sobre as convenientemente chamadas "dificuldades" do movimento.

Sem embargo quer da coragem da opção pelo exílio de desfecho incerto, quer do denodo para sobreviver às vicissitudes da política em África, aos desaires e ao isolamento15, a "luta" era, sob muitas facetas, um correr do tempo mais preenchido por questiúnculas entre os indivíduos do que por ações anticolonialistas. Mesmo que, em tese, se admita a multiplicidade de formas de luta pela descolonização de um território e que, por isso, se rejeite a redução da luta à insurgência armada estritamente considerada (DARCH, 2015), o termo mais apropriado para as ações, amiúde meramente protocolares, e para a trajetória dos independentistas será o de militância (NASCIMENTO, 2015). A creditação internacional dessa militância, rala e inconsequente, viveria do suporte dos movimentos de libertação das demais colónias portuguesas. O MLSTP inferiria

\footnotetext{
11 Tal a "luta dos nacionalistas [...] que, no exterior, forçados ao exílio, não pouparam sacrifícios, a fim de darem a conhecer ao mundo inteiro a opressão e a exploração de que era vítima o povo das nossas ilhas." (COSTA, 1978, p. 38).

12 Fundado em data incerta, o grupo denominado Comité de Libertação de São Tomé e Príncipe existia na primeira metade da década de 1960. Ao tempo, a figura proeminente era Miguel Trovoada, que vivia em Libreville. Após acusações à sua inépcia e conduta, outros sãotomenses, de que destaca Tomás Medeiros, fundaram em 1965, em Acra, um outro CLSTP, cuja ação de propaganda foi prejudicada pela convulsão política no Gana em 1966 (NASCIMENTO, 2015; SEIBERT, 2002).

${ }^{13}$ Resultado da tentativa de conciliação de vontades e de congregação de esforços dos sãotomenses exilados, o MLSTP foi fundado em 1972, na Guiné Equatorial por 8 ou 9 ilhéus (NASCIMENTO, 2015; SEIBERT, 2002).

${ }^{14}$ Por premeditação ou por azar, Tomás Medeiros foi arredado da hipótese de liderar o MLSTP.

15 Atente-se na expressão de desalento ante a possibilidade de morte que poderia nem sequer chegar a ser do conhecimento dos conterrâneos (CEITA, 2012, p. 117).
} 
A "luta" e as (in)verdades de conjuntura, a independência de São Tomé e Príncipe e a amputação das liberdades dos são-tomenses

Augusto Nascimento

do reconhecimento internacional, convencionado como sinónimo de representatividade, o direito não apenas a negociar com Portugal mas, sobretudo, a governar os ilhéus, ditos o "nosso povo". À época, decantara-se uma legitimidade assente em verdades de conjuntura acerca das independências, tudo se subsumindo a uma "luta”, idealizada, da qual os atores eram o narrador interessado.

Sem dúvida, pode considerar-se razoável o argumento da impossível luta armada nas ilhas, conquanto, contra a presunção que se torna verdade indisputada, tal não equivalha a aceitar que, se ela fosse possível, os mesmos a tivessem empreendido. Também dessa ponderosa desculpa para a inação se extorquiu uma representatividade, reconhecida mais por concertações alheias à terra do que pela sintonia dos sentimentos dos ilhéus com os desígnios políticos do MLSTP, aliás, camuflados ou omitidos ao escrutínio popular até à tomada de poder (NASCIMENTO, 2019).

Poderá haver muito a descobrir no tocante ao período da "luta". Todavia, cremo-lo, não se acrescentarão dados relevantes para escorar na "luta" a ideia de um caminho para a independência. Ao invés, talvez se ratifique a ideia do que de contingente tiveram as andanças no exílio, mesmo já depois da formação do MLSTP em 1972. O curso dos eventos autoriza a noção de que o termo "militância" - designação de ações pautadas por hiatos, pela errância - é mais apropriado do que o de "luta". Seja como for, mais relevante do que concluir se houve, ou não, "luta" nos termos feitos crer por discursos durante anos irrebatíveis, ou se será mais adequado falar de militância, talvez seja a reflexão sobre os resultados políticos da crença do "povo" (com o seu quê de forçada ou de dúplice, tal como dúplices tinham sido vários dos protestos de portuguesismo na era colonial) numa versão adornada da "luta” pelos autoproclamados dirigentes. Depois, a versão oficiosa da "luta" foi replicada por outros ilhéus, incluindo os que duvidariam da capacidade desses dirigentes para a governação ${ }^{16}$ mas que se acomodaram à situação tida por inexorável.

\footnotetext{
16 Por exemplo, alguns ithéus terão ficado surpreendidos com a proposta do MLSTP de um programa na linha dos famigerados programas mínimo e maior de outros movimentos (NEVES, 1975). Da noção do quanto a terra mudara nos anos precedentes brotava a perceção da impreparação dos futuros governantes (cf. testemunho pessoal), perceção que, todavia, o medo obrigou a calar.
} 
A "luta" e as (in)verdades de conjuntura, a independência de São Tomé e Príncipe e a amputação das liberdades dos são-tomenses

Augusto Nascimento

A palavra por ação... e a validação da "luta"

Após o 25 de Abril, circulou a alusão à "luta", da qual se inferia - e, aventarse-á, se imaginava - uma luta, qual verdade indisputável! Todavia, naquele momento, mais importante do que o conhecimento do passado era a euforia política em virtude da qual se tomava a palavra dos putativos dirigentes pela sua ação em prol da independência.

Além dos empolgantes discursos dos jovens da Cívica ${ }^{17}$ na rua, radiodifundiam-se comunicados de Libreville e escutar-se-iam discursos de Pinto da Costa. Diga-se, estes discursos viriam a ser qualificados de documentos históricos, não como fontes a interpretar, mas como sínteses indiscutíveis da "evolução da luta do povo santomense no decorrer da fase decisiva da luta de libertação nacional, na fase do Governo de Transição e ao biénio de independência" (COSTA, 1978, p. 5). Como era expectável, no tocante à "luta", um Esboço histórico dessa época era quase um decalque das palavras do então líder. Nomeavam-se o CLSTP e o MLSTP, aquele pressupostamente formado em 1960, este em $1972^{18}$, e, como nos discursos, essa nomeação equivalia à assunção implícita de ação pregressa e, por isso, de legitimidade do vindouro governo do MLSTP.

A existência, atestada pela sua criação, destes coletivos equivalia à "luta". Porém, reafirmada esta, o foco dos discursos incidia no "povo" e na marcha da história. A legitimidade política do MLSTP acabava majorada pela afirmação de que "o povo de S. Tomé e Príncipe" lutara"19 através da "tática da resistência passiva"20, depois das lutas de Yon Gato e de Amador no século XVI e da guerra

\footnotetext{
${ }^{17}$ Cerca de dois meses após o 25 de Abril, vários estudantes universitários regressaram ao arquipélago. Também em resultado de alvitres de políticos portugueses, criaram a Associação Cívica Pró-MLSTP. Com recurso a técnicas de mobilização e a uma ideologia nova, correntes nas universidades portuguesas, desenvolveram uma eficaz ação de propaganda em prol da independência sob a batuta do MLSTP (NASCIMENTO, 2015).

18 Com inexatidões, disse-se que o CLSTP se sediara no Gana até 1967, se deslocara para Brazzaville, depois para Santa Isabel e, mais tarde, para Libreville. Em 1972, num congresso, transformara-se em MLSTP (ESBOÇO, 1975, p. 19).

${ }^{19} \mathrm{Na}$ verdade, mais do que à luta anticolonial, as narrativas sumárias e truncadas respeitavam à exploração e à opressão do colonialismo, contra as quais se inferia a resistência dos colonizados. Tal constituía uma distorção, em todo o caso, difundida e aceite por não parecer possível que não tivesse havido resistência. Não obstante, a maioria das pessoas pautara-se pela acomodação.

${ }^{20}$ Acrescentava-se: "entre os torcionários da PIDE e da Polícia Militar, difícil se torna saber qual melhor serviu a repressão e a exploração” (ESBOÇO, 1975, p. 19).
} 
A "luta" e as (in)verdades de conjuntura, a independência de São Tomé e Príncipe e a amputação das liberdades dos são-tomenses

Augusto Nascimento

do mato nos séculos seguintes. Também a luta dos povos da Guiné, Cabo Verde, Angola e Moçambique e a do povo português tinham conduzido o sistema colonial-fascista a uma situação insustentável21.

Supostamente inspirador dos desígnios dos independentistas, o plurissecular passado de luta credibilizava a "luta" recente. Contudo, mais do que na evocação dos distantes "camarada Yon Gato" e "camarada Amador"22, o leitmotiv da mobilização estava na desforra dos agravos do colonialismo e nas pueris promessas de amanhãs ridentes, em que parte da população se predispôs a acreditar.

Ao aludir à "luta" do povo e ao apoiar uma "luta" a destempo e por procuração, por intermédio da Cívica, o MLSTP, entrementes reagrupado em Libreville, conseguia, primeiro, resumir as vidas pessoais a uma luta inexistente - inferida de um antagonismo irredutível inerente ao colonialismo, logicamente plausível, mas que, na verdade, não se traduzira numa luta pertinaz, nem sequer passiva $^{23}$-, mas que passava a figurar como realidade. Segundo, O MLSTP tornava-se a direção ${ }^{24}$ de um movimento, que, se dele se excluísse o "povo", inadvertidamente arrolado como militante, não existia como tal.

Com efeito, tornou-se corriqueiro aludir à direção do Movimento. Ao jeito da época, esta era outra decorrência política da mescla de ideias, lemas, crenças

\footnotetext{
${ }^{21}$ Destacava-se o descontentamento no exército português, onde as baixas eram enormes (ESBOÇO, 1975, p. 19).

22 No seu discurso de 12 de Julho, Pinto da Costa proclamou: Glória eterna ao nosso camarada Yon Gato. Glória eterna ao nosso camarada Amador! (COSTA, 1978, p. 80-81). Eram os mesmos referentes citados por Guadalupe de Ceita em 1970, em Roma, quando à menção a Gato e a Amador juntara a da guerra do mato durante três séculos e os 1032 mortos aquando do episódio de Batepá (CEITA, 2012, p. 134-135). Afora os equívocos em torno das ações de Gato e de Amador, realce-se a aplicação retroativa da noção de "povo" aos séculos anteriores, um erro de cariz histórico - nessa medida compreensível -, mas com implicações políticas.

${ }^{23}$ Ao tempo, no mundo académico refém da dicotomia ideológica, a antevisão de um confronto sem compromissos em qualquer contexto colonial constituía um axioma indubitável (a propósito da África do Sul, ver: ZIEGLER, Jean. Main basse sur l'Afrique. Paris: Éditions du Seuil, 1978.). Era da presumida irredutibilidade do confronto colonial que se inferiam as sentenças acerca da luta e resistência e se predizia o futuro. Assim sucedeu no arquipélago.

${ }^{24}$ A esta distância, afigura-se significativo do envolvimento emocional dos ilhéus que não tivesse sido possível perguntar quem eram os militantes do movimento que, anos a fio, supostamente tivera uma direção mas não militantes ou simpatizantes, só surgidos em quantidade significativa após o 25 de Abril.

Num microuniverso insular, onde todos se conheciam, a pergunta sobre os militantes era inconveniente e quando tivesse sido respondida revelaria adesões em função dos tempos que se avizinhavam... ou de motivos mais prosaicos como, por exemplo, a suspensão de quaisquer processos judiciais a quem entrementes se tornasse militante do MLSTP.
} 
A "luta" e as (in)verdades de conjuntura, a independência de São Tomé e Príncipe e a amputação das liberdades dos são-tomenses

Augusto Nascimento

e desejos que, subitamente, tinham livre curso na ilha ${ }^{25}$. Adicionalmente, os anseios independentistas tornavam-se incontestáveis, com o que se impossibilitava uma análise desapegada da evolução do colonialismo ${ }^{26}$. E, todavia, uma tal análise teria sinalizado uma fasquia de um contrato social implícito. Em vez disso, adveio uma nova "luta", que redundaria em obrigações do dito "povo".

Em síntese, pouco de significativo se dizia acerca da "luta" pela independência para além do que era acreditado como verdade irrebatível - como o deveriam ser todas as palavras dos "dirigentes" -, a saber, o de ela enfileirar na pressupostamente inexorável libertação dos povos ${ }^{27}$. Logo, a legitimidade do poder advinha da inserção da independência no progresso da humanidade, de cuja certeza poucos duvidariam. Dada a euforia despoletada pela mobilização da rua após 25 de Abril, rareava o espaço para o ceticismo sobre a evolução histórica. Com termos de referência assim tácita mas imperativamente definidos, São Tomé e Príncipe não podia senão seguir no sentido do curso previsível e desejável do progresso, pouco devendo importar as consequências concretas na vida dos indivíduos - entre eles, os que se tornavam "traidores" e "renegados" pela sua renitência a abdicar de si mesmos em prol do "povo" -, em todo o caso, negligenciáveis quando comparadas com os desígnios da humanidade redimida a que o novel país se juntava.

A legitimidade advinha igualmente do conformismo do grosso dos ilhéus, ditado pelas circunstâncias do mundo, entre elas, a surpreendente renúncia do colono. Além disso, numa sociedade pautada por décadas de acatamento da

\footnotetext{
${ }^{25} \mathrm{Na}$ ilha do Príncipe, não faltou a coerção para conter objeções e sentimentos dissonantes dos intentos do MLSTP. Curiosamente, anos depois, a um dos protagonistas nem sequer ocorria que a sua ação francamente ameaçadora pudesse ter tido uma conotação coerciva (testemunho pessoal), o que diz algo da forma como ao tempo se agiu impensadamente em nome de exaltantes objetivos políticos.

${ }^{26}$ É significativo que, numa cerimónia protocolar, um ministro do governo de transição no fim de um discurso em tudo avesso à realidade, ciente de ter sido panfletário, confidenciasse a Pires Veloso... que the que desculpasse, mas que seria assim até à independência (testemunho em segunda mão); noutro caso, a disponibilização a entidades internacionais de dados estatísticos que desmentiam as caracterizações caricaturais do colonialismo causaram uma raiva dificilmente contida a arautos do MLSTP, cf. testemunho pessoal.

${ }^{27}$ No discurso de 1 de maio de 1975, Costa referiu: "As lutas dos povos oprimidos do mundo inteiro e a luta do povo português têm influência sobre a nossa própria luta." Citou a vitória do Vietname do Sul sobre os inimigos do "povo vietnamês" (COSTA, 1978, p. 62). A convocação das várias lutas de libertação e até da luta contra o fascismo em Portugal servia para escorar a legitimidade do regime vindouro, consentânea com uma evolução inelutável. Como é óbvio, que a emancipação do arquipélago, mesmo se aparentemente inelutável, pudesse ter diferentes matizes era algo que se pretendia obnubilado.
} 
A "luta" e as (in)verdades de conjuntura, a independência de São Tomé e Príncipe e a amputação das liberdades dos são-tomenses

Augusto Nascimento

ordem decerto se suporia necessário o exercício da autoridade na governação ${ }^{28}$. A alguns ilhéus restava a esperança de que o exílio tivesse conferido a gravitas precisa aos futuros governantes.

Afora o 12 de Julho - aniversário do MLSTP e dia da independência -, as datas celebradas nos primeiros anos de independência não se referiam a episódios marcantes da "luta", mas ao "massacre de Batepá”29 e à morte de ilhéus, Giovanni e soldado Paulo Ferreira, já após o 25 de Abril, quando decorria a luta a destempo e, em parte, tolerada pelas autoridades coloniais demissionárias, incluindo militares portugueses apoiantes da independência. Acidentais, as mortes destes elementos do "povo", ocorridas num momento de tensão política que podia ter descambado em violência, foram transformadas em heroicas.

Em suma, à época, os lemas acerca de uma histórica resistência do "povo" teriam um desdobramento político, o da cimentação do poder do MLSTP, assente também na substituição do conhecimento da "luta" independentista pela celebração e aprofundamento da "luta" do "povo".

\section{A invenção do "nosso povo", a legitimidade do poder e continuação da "luta"}

A ação política dos exilados foi resumida na expressão “luta”, quando talvez cumprisse duvidar dessa "luta", sem que por isso se tivesse de duvidar do direito à independência. Todavia, em torno deste direito teciam-se ilações e imperativos que povoavam o imaginário mobilizado pela "luta" da Cívica pela independência sem delongas. O fito era o poder a despeito de qualquer consulta da vontade popular, tal a condição de um projeto político específico de independência, caucionado pela "luta", que, de resto, maiorais da terra - que, segundo os revolucionários, constituíam a burguesia local, submissa ou aliada do colono tinham achado desnecessária.

\footnotetext{
28 Para além do hábito de acatamento da autoridade - de que, pela emulação das práticas coloniais, o partido único beneficiou (NASCIMENTO, 2013b) -, a necessidade de autoridade seria, decerto, uma consideração interiorizada pelos que tinham de se conformar com a obediência a quem nunca tinham imaginado vir a obedecer.

${ }^{29}$ Mais de mil vidas dizimadas numa semana (ESBOÇO, 1975, p. 18).
} 
A "luta" e as (in)verdades de conjuntura, a independência de São Tomé e Príncipe e a amputação das liberdades dos são-tomenses

Augusto Nascimento

Com efeito, sem embargo da militância dos exilados e da "luta" da Cívica após o 25 de Abril, a independência chegava por arrasto ${ }^{30}$. Mais do que da ação do CLSTP e do MLSTP, o figurino da independência brotou da mobilização da Cívica, não contra os desamparados colonos, derrotados a 25 de Abril, mas contra os ilhéus que, mobilizados para a restituição da possível justiça após o colonialismo, estavam inadvertidamente a caucionar uma nova sujeição. Intenções à margem, a arrogada defesa dos verdadeiros interesses do "povo" abria caminho à imposição do que ao povo não interessaria. Na prática, a meta da independência transformava-se no poder de alguns. A ditadura subsequente confirmaria que a luta decisiva era pelo poder, contra o povo islenho. Afirmavase que este não se podia exprimir livremente enquanto o país não fosse livre, mas, evidentemente, não the seria dado exprimir-se livremente após a independência.

Para além de tributários das lutas noutras colónias - em resultado das quais o exército colonial exaurido abrira caminho à democracia em Portugal, um país pobre, atrasado e sequioso de progresso e onde, após quase meio século de Estado Novo, se falava de socialismo -, a independência, o regime de partido único e o poder do MLSTP dependeram da creditação internacional do MLSTP como representante do povo são-tomense, do qual era dito que lutara pela independência ou que, não tendo lutado, o teria feito se tal fosse viável. Aliás, a "luta" da Cívica, a destempo, fingindo ignorar e aproveitando a disposição descolonizadora a cada dia cada vez mais vincada na metrópole e repercutida na tolerância das autoridades nas ilhas, pretendia ser sinal dessa disposição combativa, ornada, por exemplo, com menções à "zona libertada" do Riboque ${ }^{31}$ e à presença de guerrilheiros nas Neves $^{32}$. Facto impensado nesse momento de galvanização política, a ideia de que o povo lutara era, mais do que uma nota sobre o passado, uma cobrança, se não de uma lealdade, decerto da obediência futura.

\footnotetext{
30 Também Tomás Medeiros expressaria tal opinião (LABAN, 2002, p. 206). ${ }^{1}$ Bairro na periferia da cidade de São Tomé.

${ }^{32}$ Acerca de boatos relativos à presença de guerrilheiros na zona norte da ilha de São Tomé, vejase: VELOSO, Pires. Vice-Rei do norte: memórias e revelações. Lisboa: Âncora Editora, 2008.
} 
A "luta" e as (in)verdades de conjuntura, a independência de São Tomé e Príncipe e a amputação das liberdades dos são-tomenses

Augusto Nascimento

Conquanto por regra se enfatizem as ações e as palavras convergentes com a "luta", ainda se expressaram reticências à independência do MLSTP. Entre os mais explorados ou entre os mais conservadores então desqualificados contra quem (mais do que por quem) se apregoava lutar -, alguns desconfiariam das promessas de um amanhã ridente. Numa ação de esclarecimento, elementos do famigerado "povo" terão retorquido "a Dr. a fala assim porque, quando houver problemas, a Dr. a apanha o avião..." (informação verbal) ${ }^{33} \mathrm{Na}$ contramão do pré-anunciado regime de verdade (MBEMBE, 2013, p. 83), antes de ser cerceada a expressão dos sentimentos, um ithéu ainda se atreveu a recusar a "independência familiar" (INDEPENDÊNCIA..., 1974, p. 23-24), um prognóstico sobre o desvio de finalidade do intento político do MLSTP, toscamente formulado mas mais certeiro do que o da literatura laudatória travestida de rigor lavrada nessa época.

Entrementes, parte dos ilhéus - mormente do funcionalismo, que seria cooptado - rendia-se, aderia e reproduzia o discurso que se impunha veicular a bem dos superiores interesses do "povo", em rigor, do Estado vindouro. Por força do medo inspirado pelos novos dirigentes e pelas incertezas do futuro, era difícil outra atitude que não a metamorfose do receio na adesão aos mandantes. Naquele microuniverso, decerto correriam juízos sobre a personalidade dos dirigentes, anos antes rapazes da rua. Ora, apesar da descrença, prevalecendo o medo, o futuro poder transformava os consabidos defeitos dos dirigentes em virtudes e em capacidades. A muitos ilhéus, mesmo se contrafeitos, não restou alternativa que não a de passar da aceitação resignada à adesão mais ou menos ostensiva. Só individualmente se podia fugir a tal fado e, ainda assim, incorrendo, se não em dissabores, pelo menos na condição de traidor por se renegar a pertença ao "povo". Noutros termos, após o 25 de Abril, a rendição transferia-se das autoridades coloniais para os novos mandantes. Entre a euforia e o medo, na esteira da aceitação por parte dos ilhéus mais diferenciados da sua secundarização face aos do MLSTP portadores de um novo credo, os demais deveriam convencer-se de qualquer verdade que fosse para sobreviver...

Testemunho recolhido em segunda mão, numa conversa informal em Lisboa, em data incerta. 
A "luta" e as (in)verdades de conjuntura, a independência de São Tomé e Príncipe e a amputação das liberdades dos são-tomenses

Augusto Nascimento

Com um apelo tácito a um recomeço ex nihilo, a invocação da "luta" parecia rasurar, até apagar ${ }^{34}$, o anteriormente sucedido ${ }^{35}$, com o que os dirigentes antecipavam os intentos de um Estado historiador ${ }^{36}$. Contudo, tratava-se de um apagamento envolto em contradições. Ao mesmo tempo que se mencionava a luta do "nosso povo", sem a detalhar, avultava a comparação do desempenho triunfante dos exilados com a conivência com o colono que, mesmo se forçada, prevalecera no arquipélago. Decerto corria um trato entre o esquecimento da mácula da subserviência ao colonialismo e a subsequente fidelidade ao MLSTP, nalguns casos recompensada com o acesso a algumas benesses ${ }^{37}$ inacessíveis à maioria.

Os resultados políticos da adoção da narrativa da "luta" - entre eles, o medo, o condicionamento da forma de pensar, a descrença noutras possibilidades políticas, a anuência forçosa e dúplice aos ditames dos dirigentes, chamada de consciencialização, a que se obrigaram os ilhéus - sustentariam o regime de partido único durante quinze anos e cedo malbaratariam hipóteses do futuro presumidamente melhor prometido pela independência.

Apesar do que a independência tinha de inebriante, a solução política forjada em 1974-1975 apartava-se dos desejos do grosso dos ilhéus, distantes de um regime dito revolucionário que celeremente deixou de ser uma festa, trocada que foi pelo cercear das liberdades pelas quais se alegava (equivocadamente e com reserva) ter lutado. A negação da liberdade de expressão foi adotada para prevenção da dissonância política e para a preservação da irrefutabilidade da palavra dos dirigentes. Por isso, durante anos ajudou a preservar a noção da "luta" aludida em 1974-1975.

\footnotetext{
${ }^{34} \mathrm{~A}$ agenda nacionalista baseava-se pouco na história e o passado podia ser claramente separado do presente (FALOLA, 2004, p. 53). Na verdade, apesar da evocação de heróis passados, o fito era o de um presente radicalmente novo. E, assim desenraizado dos escolhos da vida, tal presente suscitava adesão.

${ }^{35}$ Tal como o colonialismo desprezou a história, também o MLSTP, apesar de evocar o passado, queria a história começada com a independência. Do passado, o MLSTP selecionava o que queria ver lembrado.

${ }^{36}$ Sobre a pretensão estatal da definição da verdade, das visões do mundo e da orientação dos indivíduos (MBEMBE, 2013).

${ }^{37}$ Uma das benesses podia ser o acesso privilegiado a bens triviais, que nunca se imaginara virem a faltar até ao dia em que tal sucedeu. Já após o 25 de Abril, problemas de abastecimento de géneros tinham sido prontamente explicados como produto da ação açambarcadora dos colonos. Ao tempo, quem duvidaria desta explicação simplista e conveniente de um epifenómeno indiciador das consequências de um processo político de insuspeita complexidade e que não mais cessaria de surpreender?
} 
A "luta" e as (in)verdades de conjuntura, a independência de São Tomé e Príncipe e a amputação das liberdades dos são-tomenses

Augusto Nascimento

A sumária narrativa da "luta" - isto é, mais a idealização do que teria sido do que o seu relato tentativamente fidedigno - teve consequências políticas. Como recompensa, os seus arautos obtiveram o poder, o que, na época e para os jovens revolucionários, era muito mais aliciante do que o dinheiro. A transformação social do "povo" por indução do exercício do poder parecia aureolada de superioridade ética em contraponto à vulgaridade da acumulação de dinheiro.

Note-se, como alhures, o regime do pós-independência não derivou da narrativa histórica sobre a pretérita "luta" dos exilados. O apoio ao MLSTP adveio mais da antevisão do prospetivo cenário do poder após a independência do que (da narração) das práticas emancipatórias de ilhéus. Em todo o caso, uma versão histórica, sedimentada como irrebatível, teve um papel, mesmo se menor, no parto desse regime e na legitimação dos dirigentes do MLSTP. Na circunstância, teve mais impacto pela congruência com a ideia do mundo a caminhar numa dada direção. A vazão da narrativa da "luta" na política do regime de partido único vedou outros caminhos. A seu modo, era uma espécie de fim da história em função do que se interpretava o passado, cuja materialidade factual nunca se detalhava ${ }^{38}$.

Atidas ao girar do mundo, noções como a de "povo" e "luta" - abstratas e estereotipadas mas correntes no palavreado político no mundo bipolar de então - ajudaram a creditar a dita representatividade e a legitimidade do MLSTP.

A mescla entre a arvorada "luta" do "povo" - de que se citava a recusa ao trabalho nas roças ${ }^{39}$, recusa emoldurada numa intenção política assaz duvidosa, para não dizer inexistente - e a do MLSTP creditava esta "luta", qual clímax da plurissecular resistência ao colono. Tratava-se de uma extrapolação indevida ${ }^{40}$, mas, ao tempo, isso era irrelevante.

Como se assinalou, outra narrativa operante no tocante à consolidação dos objetivos políticos dos independentistas foi a da caracterização estereotipada da ação nefanda do colono, exemplificada no atraso e na pobreza resultantes da extorsão económica da terra pelos roceiros, donos das roças ou fazendas.

39 Perdura uma faceta fantasiosa na ideia de resistência dos ithéus ao trabalho nas roças, porquanto importa considerar o desinteresse dos roceiros na contratação de mão-de-obra local, para o que, não por racismo cego, mas por interesse próprio, laboraram de forma dúplice para firmar o mito da indolência atávica dos ilhéus (NASCIMENTO, 2004).

40 Tratava-se de uma inferência indevida da centralidade da resistência de povos africanos à conquista colonial ou da assunção da presumivelmente universal resistência a qualquer 
A "luta" e as (in)verdades de conjuntura, a independência de São Tomé e Príncipe e a amputação das liberdades dos são-tomenses

Augusto Nascimento

Sem embargo do ressentimento calado de ilhéus contra a sua subalternização, a "luta” não existira nos termos em que era idealizada. Mas, em 1974, sob a batuta da Cívica, a "luta” levou a juventude às ruas contra os desamparados colonos e contra outra parte dos são-tomenses até que, quando isso lhes conveio, os do MLSTP declararam que, afinal, todos pertenciam ao "povo". Obviamente, estes dizeres políticos não eram neutros no tocante aos moldes da inclusão de todos os ilhéus no "povo", adiante subsumido no Estado a que todos os ditos "nacionais" deveriam obedecer.

Mais decisiva do que a validação lógica da narrativa - em si mesma, a veracidade dos factos era negligenciada - era a simbiose das (em grande medida, imaginadas) "lutas" do "povo" e do MLSTP. Tal simbiose permitia aos dirigentes demandar aos seus concidadãos a continuidade da "luta" em nome de lutas pregressas do "nosso povo". Noutros termos, a função destas alusões era a de sugerir o regime pós 1975 como uma inevitabilidade derivada de atos pregressos e da presumida vontade dos ilhéus. Estes atos não podiam ter outra consequência que não a independência, isto é, o regime implementado pelo MLSTP, com o qual, criam os dirigentes, eles não falhariam os seus objetivos, ao invés do sucedido em países tornados independentes mas cujos povos não tinham saído da miséria e da privação ${ }^{41}$. Indisputavelmente de acordo com os "verdadeiros interesses" do "povo", consubstanciados na independência "total e completa", o MLSTP induzia, pois, à continuidade da "luta" contra o neocolonialismo e neoimperialismo. Na prática, tal redundava na demanda de trabalho estrénuo aos ilhéus e aos ex-serviçais e, ao invés das promessas, no empobrecimento de parte deles.

A independência, um suposto bem para o "povo", era um bem efetivo para alguns, conforme o evidenciou, embora involuntariamente, a atitude dos jovens

\footnotetext{
agressão, ideias generalizadas a partir dos trabalhos de Terence Ranger (ver a síntese crítica: COOPER, Frederick. Conflito e conexão: repensando a história colonial da África. Anos 90, Porto Alegre, v. 15, n. 27, p.21-73, 2008). Em todo o caso, não é claro que a resistência estivesse sempre presente e, sobretudo, que toda ela confluísse para o superveniente nacionalismo.

4 Como assinalou FALOLA, os laços neocoloniais e as propostas de desenvolvimento conducentes à maior dependência face ao Ocidente radicalizaram os académicos que adotaram o ideário marxista e a teoria da dependência (FALOLA, 2004, p. 263). Este diagnóstico do neocolonialismo era o contributo intelectual para a opção de uma África diferente, imaginada pelos do MLSTP.
} 
A "luta" e as (in)verdades de conjuntura, a independência de São Tomé e Príncipe e a amputação das liberdades dos são-tomenses

Augusto Nascimento

da Cívica que a tinham apregoado. De outro modo, não se compreenderia como, de um dia para o outro, os injustiçados jovens cívicos tenham passado das laudas ao MLSTP ao medo, a ponto de fugirem ${ }^{42}$, experimentando os efeitos da intimidação a que tinham recorrido antes. Não tinham praticado nenhum crime, mas era como se o tivessem feito. Não foram expulsos, mas deviam agir como se 0 tivessem sido. A verdade sobre quaisquer factos era aquela que os mandantes decretassem.

Lembremo-lo, a luta da Cívica tivera por intuito a imposição do projeto do MLSTP, exposto sob lemas algo ambíguos, indutores tanto de galvanização dos que saíam à rua quanto de receio que se apossava dos mais velhos e da "pequena burguesia" local. Útil até à data da marcação das negociações com o governo português, a Cívica tornou-se inopinadamente inconveniente quando a sujeição e a acomodação das pessoas aos putativos mandantes e aos desígnios do MLSTP começaram a perigar por força das tensões acumuladas com a incessante agitação de rua, com cada vez menos justificação e sem propósito visível, facto de que os do MLSTP se convenceram depois da presumível sabatina pelo altocomissário após a chegada de Pinto da Costa à ilha a 17 de março (NASCIMENTO, 2019).

Após o comício de 19 de março de 1975 e a encenação de um suposto atentado contra o primeiro-ministro, não terá sido necessário explicar aos jovens cívicos que não thes restava senão obedecer sem questionar o que quer que fosse, quando, a 14 de março, de Libreville, se ameaçara quem porventura tocasse num desses jovens. Estes não podem ter deixado de sentir como injustiça o serem escorraçados da cena política, quando, afinal, tinha sido a sua mobilização das ruas a credibilizar como "luta" o que não passara de uma ação errática e desgarrada - poderão então ter concluído, conquanto inutilmente porque a destempo - dos do MLSTP que, uma vez firmados no poder, sem sequer o assumir os expulsavam da terra prestes a tornar-se independente.

\footnotetext{
42 Seria dito que os dois ex-ministros da Cívica não tinham sido forçados a abandonar o país (COSTA 1978, p. 41), ensaiando-se, a este propósito, a troca da realidade pelas palavras, um artifício já corriqueiro e posteriormente replicado noutros processos políticos no pósindependência.
} 
A "luta" e as (in)verdades de conjuntura, a independência de São Tomé e Príncipe e a amputação das liberdades dos são-tomenses

Augusto Nascimento

Atendo-nos às (equivocadas) narrativas acerca de lutas, inquiramos: quando tivesse existido efetiva resistência política ao colonialismo, que não apenas um ressentimento calado e disfarçado, quando perdurasse memória dessa luta, tal não deveria ter dado azo a uma disputa política por um outro regime que não o do pós-independência em que, com insuspeita facilidade, se aboliram as liberdades individuais, incluindo as que a ditadura colonial no seu ocaso restaurara? Ao invés de alguma argumentação inane, a opção por um regime ditatorial - dito uma "democracia popular revolucionária" - não resultou do desconhecimento e da falta de hábitos democráticos ${ }^{43}$, resultou, sim, da escolha de um regime autoritário ${ }^{44}$ e tentativamente indutor da mudança de índole dos ilhéus, a qual deveria redundar na lealdade ao chefe.

A esta distância, sobressaem as inverdades - ou verdades de conjuntura, indisputáveis devido à exaltação política - e os saltos lógicos autenticados por lemas panfletários acerca da "luta": a verdade da "luta", de que não se duvidava em função do respaldo institucional da ONU e da OUA, decorria, sobretudo, da insanidade moral irreparável do colonialismo, de cuja caracterização, por mais panfletária ou redutora que fosse, não se podia discordar. Ora, como se disse, adensando-se o ambiente propício à mentira, mormente sobre os resultados das políticas sociais nos derradeiros anos do colonialismo, não só se baixavam os crivos de exigência relativamente ao desempenho do novo poder, como se abdicava de qualquer crítica trocada pela crença na bondade de um projeto de poder dito promotor de uma independência verdadeira ${ }^{45}$.

\footnotetext{
${ }^{43}$ Apesar da feição ditatorial do Estado Novo, o formalismo processual, necessário à governação democrática, era observado nalgumas instituições e coletividades antes do 25 de Abril. E, quando não fosse este o caso, nem por isso se tinha de inventar uma justificação para o (inconfessado) desapego por procedimentos democráticos, afinal, uma justificação tornada "teoria" para não ter de resolver a contradição entre a libertação da colónia e a sucedânea dominação dos indivíduos.

${ }^{44}$ O MLSTP contou com a ajuda da incapacidade ou do desinteresse das autoridades portuguesas demissionárias em impor regras democráticas durante a transição, preocupadas que estavam apenas em evitar o derramamento de sangue, a que acrescia o alheamento de um destino que não mais thes importava.

45 Anos após a independência, ao mais imberbe dos aprendizes de historiador não deixava de intrigar como é que do permanente débito de ideologia revolucionária as pessoas não inferiam a questionação dos privilégios em tempo de generalizadas provações extremas. Favorecida pelo medo e pela acomodação, já observáveis no tempo colonial, a constante demanda de lealdade transmudava-se na incessante réplica de um ideário revolucionário, do qual, algo paradoxalmente, não se extraía senão o alinhamento com o chefe. Ainda assim, tal não prevenia o alastramento da dissensão que grassava em surdina.
} 
A "luta" e as (in)verdades de conjuntura, a independência de São Tomé e Príncipe e a amputação das liberdades dos são-tomenses

Augusto Nascimento

As visões recentes, a recidiva no "povo" e os "colonos negros"

Admitamo-lo, devido ao afunilamento das hipóteses de evolução por um colonialismo enquistado que só tardiamente refreara a usura dos corpos africanos pelos proprietários das roças e, talvez ainda mais decisivo, por força do paroxismo da luta ideológica naquele mundo bipolar, dificilmente se imagina outra trajetória após o 25 de Abril.

No dia da independência, a 12 de Julho de 1975, nas ruas e praças decerto predominaram a adesão e o entusiasmo. Por um lado, rareariam as reticências face à magna importância da independência e, por outro, cortara-se cerce o espaço para o ceticismo e a crítica aos novos dirigentes. Ora, a despeito da euforia do momento, a representatividade dos governantes referir-se-ia a outra realidade política, que poderia ter sido avaliada, por exemplo, por eleições, que indubitavelmente o MLSTP teria ganho, mas a que não se quis sujeitar para se vangloriar de representatividade e discricionariedade irrestritas, decorrentes, não de uma maioria de votos ${ }^{46}$, mas da "luta" em nome dos "superiores" interesses "povo", de que os do MLSTP eram verdadeiros e únicos intérpretes. A recusa de um veredito popular assentava na já citada mentira, a de que o voto não poderia ser livre enquanto o país não o fosse. Num ambiente de unicidade de palavras, que parecia tornar esta locução verdadeira, a seleção da fonte de legitimidade era o objetivo da "luta". Nessa medida, a respetiva narrativa tornou-se um dos estribos do poder.

Noutros termos, a suposta desforra do racismo e o fim da exploração pelos colonos justificavam a alegria dos ithéus pela independência do país no preciso momento em que nascia nova restrição das liberdades e do espaço de decisão pessoal sobre as vidas. Afinal, não podendo distribuir as riquezas antes extorquidas pelos brancos, restando-lhe perpetuar as privações e demandar mais trabalho, o MLSTP impôs uma ditadura, mesmo se justificada por futuros ridentes e lemas de igualdade.

\footnotetext{
${ }^{46}$ Ao arrepio do resultado, prevalecia a resistência a eleições porque se queria a legitimidade fundada no processo revolucionário, se necessário, ao arrepio da vontade popular quando esta não se revelasse conforme aos "verdadeiros interesses" do dito "povo".
} 
A "luta" e as (in)verdades de conjuntura, a independência de São Tomé e Príncipe e a amputação das liberdades dos são-tomenses

Augusto Nascimento

Passados os festejos pela independência, perante dificuldades e provações antes impensáveis, os sentimentos do comum das ilhéus - nos anos seguintes, expressos à boca pequena, à guisa de contrição ou de desabafo para quem confiadamente não seria delator - divergiriam, e muito, do que era (e ainda é) julgado lógico, quer pelos políticos carecidos de justificação e de desculpas para o erróneo de suas políticas, quer por estudiosos que querem confirmar os seus apriorismos que, por vezes, têm mais de distorção ideológica do que de ponderação da realidade.

Sopese-se, pois, a hegemonia dos ditames políticos sobre o conhecimento histórico. Além dos compreensíveis adornos dos desempenhos pretéritos ${ }^{47}$, lembrem-se as memórias ${ }^{48}$ escritas em anos recentes. Dada a maior liberdade quer para desvelar quadros de litigância, quer para citar pessoas e factos gerando, por vezes, apontamentos bem mais instigantes do que os relatos conformes aos cânones -, aí se vazam abordagens reveladoras da entropia e da errância que pontuaram a "luta”. De outra natureza são as torções de raciocínio e as nuances argumentativas que influem na inversão persistente da causalidade, das intenções e dos significados, acabando por convergir na justificação não só de decisões que se vieram a revelar económica e socialmente desastrosas ${ }^{49}$, como de opções políticas que só pareceram consensuais por serem ditadas pela conjuntura, por terem sido impostas como únicas.

A espaços, persistiram os ditames sobre a conveniência dos dizeres nas narrativas históricas e, inclusive, na produção ficcional. Anos depois do fim do

\footnotetext{
${ }^{47}$ Entre outras, ver: ALEGRE, Filinto Costa. Associação cívica: movimento de libertação. [S.l.], 2010. Disponível em: http://www.telanon.info/suplemento/entrevista/2010/07/12/4740/associacaocivica-movimento-de-libertacao/. Acesso em: 10 jun. 2016.

${ }_{48}$ Alguma da produção memorialista é uma espécie de acerto de contas. Passados os tempos de controlo político, emergem narrações das intrigas que menorizam as parcerias passadas. Além do livro de Guadalupe de Ceita, citemos o de Carlos Graça (GRAÇA, 2011). Repise-se, para o conhecimento da "luta" são mais interessantes certos pormenores e comentários do que as sínteses e as narrativas da "luta”.

Apesar de não se tratar de livros de memórias, assinale-se o facto de a "luta" quase não existir num testemunho do primeiro presidente (COSTA, 2011) e numa quase hagiografia de Patrice Trovoada, filho de Miguel Trovoada (SANTOS, 2014).

${ }^{49}$ A análise dos resultados dessas políticas, refletidas na decrescente produção de cacau das roças nacionalizadas, não cabe neste texto. Note-se, não se dirá, por exemplo, que, após o abalo do período de transição, as roças pudessem ter continuado a ser suficientemente rendáveis para roceiros e justas do ponto de vista salarial, disputa a que, muito provavelmente, se somaria a da entropia derivada da tensão inerente ao trabalho braçal na terra para outrem, ademais, num contexto diverso do colonial.
} 
A "luta" e as (in)verdades de conjuntura, a independência de São Tomé e Príncipe e a amputação das liberdades dos são-tomenses

Augusto Nascimento

regime de partido único, Tomás Medeiros viu interditada a publicação de Quando os cucumbas cantam por a obra representar o "fim do MLSTP" (informação verbal) ${ }^{50}$. Diga-se, não seria o fim do partido histórico da independência, mas a trama ficcional representa uma interpelação de um ex-militante em termos inimagináveis e de impossível resposta.

De outra perspetiva, atentemos numa alocução celebrativa da Cívica ${ }^{51}$, que indicia os dilemas que atravessam a sociedade islenha ${ }^{52}$ e que turvam a análise dos eventos, suscitando a questão: ninguém exporá outras versões? A ausência de outras opiniões não brota da falta da liberdade, brota do desinteresse e, porventura, da desafeição por tudo quanto, sendo do foro historiográfico, parece padecer da sujeição à política. Décadas volvidas, uma vez mais se ensaia um fechamento da narrativa da história: todos reconhecem o papel da Cívica, para a maioria, um papel importante, e, inferir-se-á, o "povo" - a entidade imaginada de que alguns acabaram excluídos - apoiava o MLSTP e a independência. Ora, sobra a questão de saber como tão facilmente se liquidou a Cívica com meia dúzia de palavras no comício de 19 de março de 1975. Obviamente, não foram as palavras de Pinto da Costa que liquidaram a Cívica, foi a perceção, desconcertante para os jovens cívicos, de que parte do povo - mormente, os soldados ilhéus obedientes a um comandante branco -, organizado para os apupar, seguia um guião, surpreendentemente firmado pela calada entre a autoridade por eles apodada de colonialista e a cúpula do MLSTP, que, sem mais, lhes ordenava obediência, os descartava e, nessa medida, os humilhava pública e irremediavelmente.

Voltando à citada alocução, o seu propósito seria o de obstar ao apagamento da memória da Cívica, devido a uma conspiração de silêncio com que os próprios elementos da Cívica teriam sido coniventes ${ }^{53}$. Contra esse

\footnotetext{
Testemunho em segunda mão, em São Tomé, há anos.

51 TINY, Carlos. O papel da Associação Cívica pró-MLSTP na luta pela independência. 2015 http://www.telanon.info/destaques/2015/07/14/19652/o-papel-da-associacao-civica-promlstp-na-luta-pela-independencia/, acesso: 14 de Julho de 2015.

52 Tais dilemas são insolúveis, desde logo por ninguém poder firmar em bases credíveis um cenário futuro do país. Deste quadro resultará a crença, só aparentemente paradoxal e surpreendente, nas mais delirantes promessas e em miríficas redenções (NASCIMENTO, $2013 a$ ).

${ }^{53} \mathrm{E}$, face à recidiva na escolha do que se diz, não caberia indagar as razões da opacidade? De outro modo, parecendo que se avança no conhecimento, é como se permanentemente se encobrisse a história.
} 
A "luta" e as (in)verdades de conjuntura, a independência de São Tomé e Príncipe e a amputação das liberdades dos são-tomenses

Augusto Nascimento

silêncio, reafirmou-se que a Cívica jogou um papel importante na derradeira fase da libertação da pátria. Alguns odiaram a Cívica, mas todos conheceram a ação da Cívica, na esteira das lutas de Yon Gato e de Amador e da "longa e dura luta do povo santomense". Listados nomes de ilhéus simpatizantes da independência, pretendeu-se justificar a Cívica a coberto da ideia de que "todos juntos nos batemos pela independência” 54 .

Ora, mesmo após o 25 de Abril, nem todos se bateram pela independência e, menos ainda, pela do MLSTP e da Cívica. A anuência a esta arvorada unanimidade em nome da bondade do propósito político equivale a condicionar a elaboração da história, desde logo por se menosprezar as vozes dissonantes que não eram menos são-tomenses por pensarem noutras soluções, as quais, aliás, os mesmos que enaltecem os feitos "revolucionários" do passado vêm agora e à boca pequena reconhecer que porventura teriam sido preferíveis. Repetindo-nos, e não se trata de um pormenor atentos os sacrifícios demandados em nome de uma igualdade imperativa, por muito que se evoquem "todos", o ganho foi de alguns.

Dito de outra forma, a generosidade dos propósitos expetativas e de eventuais sonhos não podem validar narrativas distorcidas do processo histórico. A fome não era um espectro nos derradeiros anos do colonialismo e era em razão deste adquirido que se projetava um futuro melhor após a independência, quando, presumia-se, as condições de vida só podiam melhorar ${ }^{55}$. Quem contradiria tal sentença? Dir-se-á que ninguém prediria que a situação económica pioraria e que as condições de vida regrediriam. Todavia, alguns previram a queda de produção de cacau resultante da nacionalização e outros atempada e repetidamente anteciparam a falência da disposição para trabalhar nas roças, entrementes arruinadas. Logo nos primeiros anos de independência, chegou-se ao aparente paradoxo de trabalhadores e mais gente da rua, desprezando a ideologia, sem nada mais poderem fazer, terem por preferível o

\footnotetext{
54 TINY, Carlos. O papel da Associação Cívica pró-MLSTP na luta pela independência. [S.l.], 2015 http://www.telanon.info/destaques/2015/07/14/19652/o-papel-da-associacao-civica-promlstp-na-luta-pela-independencia/. Acesso: 14 jul. 2015.

${ }^{55} \mathrm{Em}$ todo o caso, a plausibilidade da crença decorria, sobretudo, do desejo dos que saíram às ruas em 1974, seguindo os jovens da Cívica. Nessa altura, já eram bastantes os indícios de que o progresso não era uma inevitabilidade após as independências (COOPER, 2016, p. 43).
} 
A "luta" e as (in)verdades de conjuntura, a independência de São Tomé e Príncipe e a amputação das liberdades dos são-tomenses

Augusto Nascimento

tempo do colono... É legítimo supor que, a par da quase silenciada greve na roça Rio do Ouro ${ }^{56}$, a inexistência de greves nas roças se terá devido a medidas intimidatórias, como o envio de tropa para as roças para as defender dos inimigos do povo (COSTA, 1978, p. 138.) A quem é que este argumento não terá parecido risível? E, a ter sido assim, como não inferir um clima de duplicidade, similar ou até maior do que a prevalecente na era colonial, pois que a "política" se tornara central na vida das pessoas?

Em nome da igualdade total, não concretizada senão na rasura de interesses pessoais e no abaixamento de aspirações básicas, aliás, defraudadas, alguns militantes do MLSTP conseguiram herdar, embora metamorfoseados, os privilégios dos colonos e exercer o poder, só em tese, a benefício de todos. Após o fim do regime de partido único, as desigualdades medraram infrenes. E assim seguem hoje. Por isso, soam estranhas as alusões à união do "povo" pela independência, o que só será verdadeiro se do "povo" se tiver uma aceção instrumental, ainda atida a tornar indisputável a validade daquilo que os que têm voz queiram dizer, livremente e sem consequências, acerca de suas pregressas ações.

Porém, este arrogado monopólio da palavra por vezes traz consequências indesejadas. Qual ofensa irreparável pelo seu presumido acinte, a expressão "colonos negros" - usada na ressaca da conquista da maioria absoluta de deputados em 2014 pela ADI e da eleição do seu presidente, Evaristo Carvalho, sob a batuta de Patrice Trovoada ${ }^{57}$ - visou os que estiveram no poder após 1975. Em rigor, a expressão não se aplicará aos antigos dirigentes do MLSTP, desde logo por, esborratada a coincidência da clivagem étnica com a divisão de trabalho nas roças nacionalizadas, ter deixado de existir exploração assente na clivagem racial. Contudo, saliente-se que ela fere porque as desigualdades entre ilhéus ganharam dimensões impensáveis. Durante anos, o crescente fosso foi obnubilado pela barragem ideológica sobre a igualdade, que, reconhecer-se-á, tinha pouco ou nenhum conteúdo substantivo ou era definida pela supressão de interesses próprios e específicos de grupos e indivíduos. Para além da crítica

\footnotetext{
56 Revolução no12, p. 2-3, 7 dez. 1975.

Ver: $\quad$ http://www.parvodigital.info/index.php/noticias/politica/item/3250-em-saotome-eprincipe-cai-o-poder-dos-colonos-negros. Acesso: 27 ago. 2016.
} 
A "luta" e as (in)verdades de conjuntura, a independência de São Tomé e Príncipe e a amputação das liberdades dos são-tomenses

Augusto Nascimento

implícita, o rasgar de vestes por esta acintosa comparação entre quem tomou o poder em 1975 e os colonos também se deverá à remanescente incapacidade de análise do processo que, de uma qualquer forma, não deixou de envolver todos os ilhéus.

Após anos de um panorama politicamente aberto, plural e competitivo, o conhecimento tem um peso muito relativo, se é que preserva algum. Também por isso, as deturpações já não causam os danos políticos de outrora. As consequências resumem-se aos equívocos historiográficos - de limitado efeito porquanto é escassa e de reduzido impacto a produção local - e à erosão da palavra dos que, tendo sido atores, ainda querem ditar a narrativa. A sentir-se, uma consequência do viés comemorativo de factos controversos será a do afunilamento de possibilidades de diálogo e de um consenso político e social mínimo. Todavia, os óbices decisivos ao diálogo nos planos político e do conhecimento decorrerão de outras circunstâncias que não as palavras. Afinal, só na medida em que interessa ao exercício do poder e à disputa pela riqueza, os políticos evocam, não raro a despropósito, os heróis e o passado.

\section{Notas finais}

Após o 25 de Abril, a rarefeita narrativa da "luta", de contornos vagos mas oficiosa, apoiava-se menos em evidências empíricas - por grosso, atidas ao exílio de um punhado de ilhéus que se tornaram a direção de um movimento inexistente para além deles mesmos - do que numa amálgama de verdades de conjuntura, reverberadas na prática política e ditadas pelos putativos dirigentes. Como o anterior palavreado colonialista, a narrativa da "luta" era um discurso autorreferenciado e insuscetível de ser rebatido, fosse pela sua lógica esquiva ao confronto com a realidade, fosse por ser validado por indisputados ditames de autoridade em que se baseava a ação política, mesmo se esta se anunciava como emancipadora.

Para o historiador, é mais do que notória a discrepância entre o que foi "luta", o que se disse ter sido a "luta" e o que ainda hoje se narrará sobre essa "luta”. Note-se, da mudança de opinião relativamente à independência de alguns dos seus arautos não resultará perplexidade. Esta resulta, sim, de essa mudança 
A "luta" e as (in)verdades de conjuntura, a independência de São Tomé e Príncipe e a amputação das liberdades dos são-tomenses

Augusto Nascimento

de opinião coexistir com o pertinaz enaltecimento de ações da "luta" que permaneceriam exaltantes malgrado as suas reconhecidamente danosas consequências políticas e sociais. Com efeito, não bastaria o conglomerado de argumentos e razões em torno da independência já ser intrincado e confuso por exemplo, os encómios à Cívica e ao MLSTP esquecem que estas organizações ajudaram à imposição de um regime ditatorial -, ainda acresce o facto de se ignorarem as consequências penosas na vida de muitas pessoas. Ademais, enquanto os revolucionários e socialistas de então são hoje privilegiados, muitos ilhéus não vislumbram o mínimo laivo de esperança numa vida minimamente digna ${ }^{58}$.

Na esteira de uma avaliação do processo histórico enviesada pela empatia com as intenções, qualquer preito de homenagem ao discurso político acaba por o ser também à duplicidade de quem, tendo imposto sacrifícios ao "povo" em nome da igualdade a um tempo imperativa e utópica, vive hoje na abastança que afronta a mais gritante das pobrezas. Diferentemente da insanidade matricial do colonialismo, a assimetria de hoje é sanável, mas não se descarte a hipótese de ela porventura poder ser mais duradoura do que o colonialismo.

Fora do terreno das lutas políticas, não cumpriria ao historiador criticar as ações de protagonistas, nem sequer para lembrar, por exemplo, que pouco importa terem sido independentistas quando as políticas se traduziram numa deriva negadora dos anseios de independência ou na construção de uma sociedade oposta à prometida. Seja como for, para o conhecimento é fulcral o sentido crítico relativamente a qualquer ação, incluindo as dos independentistas. Nada obriga os historiadores a aceitar a narrativa da "luta” pelo seu valor facial e, consequentemente, a validar o projeto político de independência do MLSTP em nome de uma implícita hierarquização ética à luz dos valores da época - nessa medida, imperativos, é certo - que, afinal, custou caro aos que tiveram de

\footnotetext{
58 No plano material, a distribuição da pobreza é assaz desigual, atingindo em particular os mais velhos e os que jazem nas ruínas das antigas roças abandonadas. Não é incomum as instituições internacionais e políticos locais reconhecerem a pobreza extrema, mormente por ocasião de pleitos eleitorais, quando enunciam a intenção de a erradicarem no prazo de anos. Ver, por exemplo, Pobreza em São Tomé deve-se a desencontro entre Governo e Presidente (noticiasaominuto.com), acesso; 25 de fevereiro de 2021. Como indício da persistência do problema, veja-se, por exemplo, São Tomé e Príncipe resgata mais de 14 mil Famílias em situação de pobreza extrema - STP-PRESS (stp-press.st). Acesso: 25 fev. 2021.
} 
A "luta" e as (in)verdades de conjuntura, a independência de São Tomé e Príncipe e a amputação das liberdades dos são-tomenses

Augusto Nascimento

arrostar com as consequências inimagináveis de uma independência, sobre a qual thes foi interdito pronunciarem-se por prontamente se thes ter cerceado a liberdade.

Por força da euforia com a independência vindoura que validou a narrativa da "luta", não é estranho que esta "luta" se tenha tornado mote de discursos. Porém, estranha-se que os motes panfletários se tenham tornado verdade histórica por tantos anos. No tocante a 1975, a surpresa atém-se ao facto de a legitimidade dos independentistas não assentar na ênfase na "luta", noutros países patente na descrição de atos heroicos, sendo o passado apresentado como um valioso instrumento para construir o nacionalismo e criar um estadonação forte (FALOLA, 2004, p. 223). Ao invés, no arquipélago, o ganho de legitimidade implicava conter o conhecimento das vicissitudes da "luta". A exaltação política ia na razão direta da ocultação das ações da "luta”, ao mesmo tempo que se inventavam outras, mormente as do "povo". A dominação pelo MLSTP assentava na modelação da interpretação da história a partir das crenças em futuros ridentes e num passado de "luta" que, de forma só aparentemente paradoxal, não era narrado, antes era mantido como uma reserva de fé para "crentes" ou consciencializados. Ato contínuo, a crença na "luta" criava uma obrigação de lealdade aos dirigentes, que se desdobrava numa exigência de uma mudança da índole dos são-tomenses, instados a concretizar o ideal do homem novo (NASCIMENTO, 2014).

Para além dos limites da historiografia nacionalista na promoção da ideia de estado-nação59 ou da coesão política, o saber, se feito serventuário de causas (insuspeitamente) particulares, tenderá a acumular fragilidades. De alguma forma, e na esteira da desertificação cultural no tempo colonial (NASCIMENTO, 2008), tal sucedeu no arquipélago após a independência. O discurso histórico foi posto ao serviço de demandas políticas de um grupo e, depois do fim da hegemonia da ideologia, o discurso histórico enredou-se na ambiguidade. Daí a tácita subalternização da "luta" a um (impossível) "herói” da independência no século XVI, como agora se quer que tenha sido Amador. Antes quase

\footnotetext{
${ }^{59}$ Acerca das vicissitudes políticas, das fragilidade dos novos estados independentes e dos limites da historiografia nacionalista (FALOLA, 2004, p. 246).
} 
A "luta" e as (in)verdades de conjuntura, a independência de São Tomé e Príncipe e a amputação das liberdades dos são-tomenses

Augusto Nascimento

desconhecido, teve de ser reinventado um passado heroico para induzir afetividades que a "luta" do MLSTP - hoje também desacreditada pelas suas políticas após a independência - não suscita.

Afora o pesado fardo do colonialismo, a que acresceu o das vicissitudes políticas em anos recentes, São Tomé e Príncipe tem características particulares em seu desfavor: entre outras, o isolamento e a exiguidade, a pobreza e as múltiplas dependências que militam contra o desenvolvimento, a liberdade e, em particular, a independência e a autonomia do saber. Contudo, e a bem do possível rigor, a vertigem de tomar o ilusório por saber adquirido e o mirífico por redenção não constituem um atributo exclusivo dos são-tomenses.

\section{Referências}

CEITA, João Guadalupe Viegas de. O memórias e sonhos perdidos de um combatente pela libertação e progresso de São Tomé e Príncipe. [S. l.: S. n.], 2012.

CHAVES, Rita. Autobiografias em Moçambique: a escrita como monumento (2001-2013). Revista de História, São Paulo, n.178, a03118, 2019.

COOPER, Frederic. Histórias de África: capitalismo, modernidade e globalização. Lisboa: Edições 70, 2016.

COSTA Manuel Pinto. Discursos. São Tomé: AHSTP, 1978. v. 1.

COSTA Manuel Pinto. Terra firme. Porto: Afrontamento, 2011.

DARCH, Colin. Um olhar de fora: a história da luta armada em Moçambique e os desafios da comunicação científica. [S.l.], 2015. Disponível em:

https://www.academia.edu/36754829/A Hist\%C3\%B3ria da Luta Armada de Li berta\%C3\%A7\%C3\%A30 de Mo\%C3\%A7ambique e os Desafios da Comunica\% C3\%A7\%C3\%A30 Cient\%C3\%ADfica. Acesso em: 16 abr. 2021.

ESBOÇO histórico das ilhas de S. Tomé e Príncipe. S. Tomé: Imprensa Nacional, 1975. 
A "luta" e as (in)verdades de conjuntura, a independência de São Tomé e Príncipe e a amputação das liberdades dos são-tomenses

Augusto Nascimento

FALOLA, Toyin. Nationalism and african intellectuals. Rochester: University of Rochester Press, 2004.

GRAÇA, Carlos. Memórias políticas de um nacionalista santomense sui generis. Lisboa: UNEAS, 2011.

INDEPENDÊNCIA dos territórios ultramarinos. Semana ilustrada, [s.l.], n. 372 , p.23-24, 7 ago. 1974.

LABAN, Michel. São Tomé e Príncipe: encontro com escritores. Porto: Fundação Eng. António de Almeida, 2002.

MBEMBE, Achille. África insubmissa: cristianismo, poder e estado na sociedade pós-colonial. Mangualde: Edições Pedago, 2013

MEDEIROS, Tomás. Quando os cucumbas cantam. Lisboa: Althum.com, 2016.

NASCIMENTO, Augusto. Escravatura, trabalho forçado e contrato em S. Tomé e Príncipe nos séculos XIX-XX: sujeição e ética laboral. Africana Studia, Porto, 7, p. 183-217, 2004.

NASCIMENTO, Augusto. Ciências sociais em S. Tomé e Príncipe: a independência e o estado da arte. Porto: CEAUP, 2008.

NASCIMENTO, Augusto. As pulsões na política em São Tomé e Príncipe. Africana Studia, Porto, n. 20, p. 135-152, $2013 a$.

NASCIMENTO, Augusto. Os dividendos do autoritarismo colonial: o impacto e a manipulação do legado colonial na configuração do pós-independência em São Tomé e Príncipe. In: PIMENTEL, Irene; REZOLA, Maria Inácia (org.). Democracia, ditadura. memória e justiça política. Lisboa: Tinta-da-China, 2013b. p. 259-282.

NASCIMENTO, Augusto. São Tomé e Príncipe: pelo trabalho, o homem novo e o socialismo contra os costumes da terra. Anuário Antropológico, Brasília, v. 40, n. 1, p. 133-163, 2014.

NASCIMENTO, Augusto. A inelutável independência ou os (in)esperados ventos de mudança em São Tomé e Príncipe. In: ROSAS, Fernando; MACHAQUEIRO, Mário; OLIVEIRA, Pedro (org.). O adeus ao Império. Lisboa: Nova Vega, 2015. p.175-190.

NASCIMENTO, Augusto. São Tomé e Príncipe: as tramas da política e a emancipação do saber histórico. São Tomé: BISTP, 2019. 
A “luta” e as (in)verdades de conjuntura, a independência de São Tomé e Príncipe e a amputação das

NEVES, Fernando. Negritude, independência, revolução. Paris: Edições etc., 1975.

SANTOS, Carlos Oliveira. Patrice Trovoada: uma voz africana. Lisboa: Âncora Editora, 2014.

SEIBERT, Gerhard. Camaradas, clientes e compadres: colonialismo, socialismo e democratização em São Tomé e Príncipe. Lisboa: Vega, 2002. 